\title{
An Investigation of Physical Attributes Relevant to the Informal Street Hawking in the Urban Spaces of Dhaka City
}

\author{
${ }^{*}$ Abontika Sara Israt, Dr. Mastura Adam \\ * Department of Architecture, Faculty of Built Environment, University of Malaya, Kuala Lumpur, \\ Malaysia. \\ *abontikasara@gmail.com \\ Received: 16 December 2015 Final Version Received: 22 October 2016
}

Making places for people ascertain the idea that the physical elements, activities and meaning are tied in the art for life. This paper focuses on the effects of informal street hawking in the urban spaces in Dhaka city. The urban informal sector is a vibrant section of the urban economy worldwide. An organized street hawking in the urban spaces could be part of city precedence for the benefit of the city community. However, the informal street hawking are always perceived to be a negative element of urban setting. Therefore, this paper investigates the issues and problems associated with the street hawking in the urban spaces based on users' perception. To evaluate the influence of physical attributes in using the urban public spaces a multiple sources of evidence, which included the questionnaire survey and physical observation,were carried out in two study areasinDhaka city. This study used a case study approach to make a comprehensive understanding of the current condition of street hawking in the city. The findings revealed that the deterioration of physical attributes is associated with the street activity and influences the users' perception of the public places. The paper recommendedon the potentiality of street hawking and its improvement forthe society and economy, therefore, space organization is essential in making sustainable city community.

Key words:Urban Public Spaces, Street Hawking, Physical Attributes,Space Organization,Dhaka

\subsection{INTRODUCTION}

Urban spacesare a result of urbanization of cities. They are an inseparable part of the spatial structure of a city comprising of squares and streets defining so many functions associated with it(Krier, 1979). Urban space is the public realm which provides the terrain for social interaction and a significant part of a city's transaction through the market squares, street hawking, shop frontages and sidewalk cafes(Montgomery, 1998). However, the integration of informal street hawking in the urban public spaces is always exaggerated withnegativeperceptions of the local authority and city dwellers (Bhowmik, 2005).

This paper highlights the issues and problems that affectthe informal street hawking in the urban public spaces of Dhaka city.Themainfocus ison two integrated subjects-the use of urban public spaces and the street hawking. People's public life in developing citiesis recognized to have the capability of diversity, uses and activities, access and linkage,comfort and safety; andphysical quality offered by that particularspace. So far, the deterioration of physical quality of the urban environment due to improper street activity impedes the livability of developing cities like Dhaka. However, of thedifficulties like; the dense population, encroachment of footpath, improper streetscape and poor management system; a large number of city dwellers depend on this activity to sustain their daily expenses as a job or for shopping. Diverse functional and leisure activities need to be added to public spaces for the city dwellers (Nilufar, 1999).With regard to this issue, this paper attempts to examine the current physical features of street hawking activity in the urban spaces. In order to fully understand the impact of street hawking, the users' perception of the attributesin public spaces wasexamined. From the present investigation, this study aims to recommend a set of criteria for the conceptualization of responsive public spaces capable of supporting street hawking in Dhaka.

\subsection{LITERARURE RIVIEW}

2.1 The Informal Street Hawking In The City Retail has a key role in urbanization in three aspects. First, as a high-value land use, retail is one of the drivers in the economics of urban land 
prices. Second, retail functions as a major attractor of pedestrian and vehicular movements, and thus, it affects the patterns of urban activities and space use. Third, retail frequently offers the first form of employment to rural migrants arriving in a city, particularly in developing nations. Thus it generates spontaneous growth of planned and unplanned retail development. But, in reality, the apparent chaos in the urban marketplaces in developing countries is more apparent than real(Findly, Paddison, \& Dawson, 1990).In the global phenomena, 'Marketplace' is an open space where a market is formerly held in a town with several leisure and street activities. The intervention of new shopping malls or roads implies eviction for the urban poor who depend on the street (Brown, 2006). Then again, there are so many developed countries who successfully tie informal hawking to part of their economy, i.e. the Covent Garden Market, London; LaRamblas, Barcelona; Singapore's Chinatown; street markets of Kuala Lumpur and Bangkok are name of a few.

Street hawking is a very common scenario in Dhaka city. The existing public spaces are frequently threatened by the encroachment of the street hawkers. Hawkers do not follow any guidelines as to be located (Bhowmik, 2005). The hawkers always claim place near public areas (parks, bus or railway terminals, offices, schools, and so on) where people can easily buy necessary goods for their daily needs. As long as the urban informal economy grows, informal economic work areas or locations will be limited(Yankson, 2000). Thus, inDhaka, an uncontrolled street hawking has created "informal" bazaar areas in public places. This phenomenon is more prevalent in the central retail area that has "naturally sprouted" in New Dhaka (Hossain, 2001).The local authorities treats street hawking as an illegal trade in the urban area of Dhaka City (Parvin, 2007).According to 2012 Strategic Transport Planning Report, the Dhaka Metropolitan City has approximately $388 \mathrm{~km}$ of footpaths for the movement of city dwellers; however, the hawkers have occupied approximately $155 \mathrm{~km}$ of these footpaths. The occupied pedestrian spaces have forced pedestrians to walk on the roads close to the car traffic environment. Consequently the lack of physical quality of the urban spaces of the city along with this activity leads the urban population to an unlivable condition.

\subsection{Theories On The Attributes of Public Spaces Relevant To Informal Street Hawking}

There are a number of theories and concepts used by scholars in multiple disciplines to characterize the city and people's' activity. It has been identified that there are several dimension on how to understand the urban design. Kevin Lynch (1981) found that, 'Vitality, Sense, Fit, Access and Control' are the five dimensions of a good city form. A different dimension were later developed representing Lynch's theory, which developed the factors that is essential for future good environment and influence the degree of image ability while walking through the central core of a city has been extracted through : livability, identity and control, access to opportunities, imagination and joy, authenticity and meaning, community and public life, urban self-reliance and an environment for all(Appleyard, 1981). Buchanan (1988) argued that urban design was 'essentially about place making, where places are not just a specific space, but all the activities and events that make it possible'. To maximize the degree of choice to users, a guideline has been set to make the built environment more responsive to shape the activities of people. A responsive environment entailsof permeability, variety, legibility, robustness, visual appropriateness, richness and personalization (Bentley et.al,2008). Permeability is how easily people can move through an environment depending on the paths located in the space. Vitally states the range of activities offered by the space. Legibility is how easily people can decide where to and how to go by forming a clear image of the place. Robustness refers to how a single space can be transformed to multipleuses. Visual appropriateness assists people to understand how to make appropriate use of a space. Richness is the sensory experience of a space and personalization is the ability to customization of a space.

An active use of public spaces can promote the logic of successful place (Gehl, 1987). A further step has been established by The Project for Public Space (PPS) in 2001.They had identified four key attributes of successful public places: comfort and image; access and linkage; uses and activity; and sociability. A sociable place should encompass people friendly environment. The uses and activities in a space generally depends on how people use the space, 
how many choices of things to do there and how the physical elements of the space encourage people to involve themselves favorably with the environment. Users' always judge accessibility of a place by its connections to its surroundings, both visual and physical. Comfort and image of a place also make a good first impression to the users of it with security, landscapes and maintenance system.

All these delineations guide some objectives of urban design relating to the concept of public space. A public space should have a character ofits own identity, continuity and quality of the public realm, ease of movement legibility, adaptability and diversity. Therefore, in developing countries street hawking is one of the significant activities in an urban public space. To present an outline for the examination of the attributes of public spaces relevant to the street hawking were identified through prominent literature review between 1961 and 2012(see Table 1). Here the selected attributes are the most frequently referred and mentioned attributes of various references.

Table 1:Summary of the theories according to place relevant attributes related to informal street activities in public places

\begin{tabular}{|c|c|c|c|c|c|c|c|c|c|c|c|c|c|c|c|c|}
\hline \multirow{2}{*}{\multicolumn{2}{|c|}{$\begin{array}{c}\text { Attributes of Public } \\
\text { places }\end{array}$}} & \multicolumn{15}{|c|}{ Researchers } \\
\hline & & $\begin{array}{l}\text { Jane } \\
\text { Jacobs } \\
\text { (1961) }\end{array}$ & $\begin{array}{l}\text { Relph } \\
\text { (1976) }\end{array}$ & $\begin{array}{l}\text { Lynch } \\
\text { (1981) }\end{array}$ & $\begin{array}{l}\text { Bentley, } \\
\text { Alcock, } \\
\text { Murrain, } \\
\text { McGlynn } \\
\text { \& Smith } \\
\text { (2008) }\end{array}$ & $\begin{array}{l}\text { Gehl } \\
\text { (1987) }\end{array}$ & $\begin{array}{l}\text { Whyte } \\
(1988)\end{array}$ & $\begin{array}{l}\text { Dewar } \\
\text { and } \\
\text { Watson } \\
(1990)\end{array}$ & $\begin{array}{l}\text { Francis } \\
\text { (1991) }\end{array}$ & $\begin{array}{l}\text { Rubenst } \\
\text { ein } \\
\text { (1992) }\end{array}$ & $\begin{array}{l}\text { Proshasky, } \\
\text { Fabian, \& } \\
\text { Kaminff, } \\
\text { (1995) }\end{array}$ & $\begin{array}{l}\text { Marcus } \\
\& \\
\text { Francis } \\
\text { (1998) }\end{array}$ & $\begin{array}{l}\text { Frey } \\
\text { (1999) }\end{array}$ & $\begin{array}{l}\text { Duany, } \\
\text { Later- } \\
\text { Zyber, } \\
\text { and } \\
\text { Speck } \\
\text { (2000) }\end{array}$ & $\begin{array}{l}\text { Shaftoe } \\
\text { (2008) }\end{array}$ & $\begin{array}{l}\text { Wagner } \\
\& \text { Caves } \\
\text { (2012) }\end{array}$ \\
\hline \multirow{8}{*}{ ن⿺辶- } & Accessibility & & $\checkmark$ & $\sqrt{ }$ & & $\sqrt{ }$ & $\sqrt{ }$ & & $\sqrt{ }$ & $\checkmark$ & & $\sqrt{ }$ & $\sqrt{ }$ & $\sqrt{ }$ & $\checkmark$ & $\sqrt{ }$ \\
\hline & Legibility & $\sqrt{ }$ & $\sqrt{ }$ & $\sqrt{ }$ & $\sqrt{ }$ & $\sqrt{ }$ & $\sqrt{ }$ & $\sqrt{ }$ & $\sqrt{ }$ & $\checkmark$ & $\checkmark$ & $\sqrt{ }$ & & $\checkmark$ & & $\checkmark$ \\
\hline & $\begin{array}{l}\text { Diversity and } \\
\text { choice }\end{array}$ & $\checkmark$ & $\checkmark$ & $\checkmark$ & $\checkmark$ & & $\checkmark$ & $\checkmark$ & $\checkmark$ & $\checkmark$ & $\sqrt{ }$ & & & & $\checkmark$ & $\checkmark$ \\
\hline & Street scape & & & $\sqrt{ }$ & & $\sqrt{ }$ & & & $\sqrt{ }$ & $\sqrt{ }$ & & $\sqrt{ }$ & $\sqrt{ }$ & & & $\checkmark$ \\
\hline & $\begin{array}{l}\text { Safety and } \\
\text { Security }\end{array}$ & $\checkmark$ & & & $\checkmark$ & & $\sqrt{ }$ & $\checkmark$ & $\sqrt{ }$ & & $\checkmark$ & & $\checkmark$ & $\sqrt{ }$ & & $\sqrt{ }$ \\
\hline & Comfort & & & & $\checkmark$ & & & $\checkmark$ & $\checkmark$ & $\checkmark$ & $\checkmark$ & & & $\checkmark$ & $\sqrt{ }$ & \\
\hline & $\begin{array}{l}\text { Pollution } \\
\text { Reduction }\end{array}$ & & & & $\sqrt{ }$ & $\sqrt{ }$ & & & $\sqrt{ }$ & & & & & & $\sqrt{ }$ & $\checkmark$ \\
\hline & Human needs & & $\checkmark$ & $\checkmark$ & $\checkmark$ & $\checkmark$ & & & $\checkmark$ & & & $\checkmark$ & & $\checkmark$ & $\checkmark$ & $\checkmark$ \\
\hline
\end{tabular}

Adapted from Carmona (2010), Source: Author, 2015

\subsection{The Influence of Users' Perception On The Attributes Of Public Spaces}

Users play a key role to perceive a space. The range of engagement of the users in a public space influenced by the attributes associated with that particular place. Generally streets are the best places for economic and social interactions in the urban context. A city can be characterized through the perception of its people (Shuhana \& Norsidah, 2008). In order to attract the users' to the areas, direct relationship between building uses, activity and products offered needs to be emphasized (Shuhana et al., 2004).The physical quality of a place contribute to make places more legible to the users (Lynch, 1960). Streetscape, diversity of choice, safety and comfort supports the assignation of users to a public place. The successful consequences of the process of place making for the people must have the capacity to offer more choices of social activities as well as being a place of cultural exchanges (S. Shuhana et al., 2004).

Dhaka city has multicultural layers of architectural influences. The function of the traditional streets in Dhaka is also places for social interaction whereby the crowds are found on the streets engaged in selling and buying activities (Hossain, 2001). In this regards, the user's perception of shopping streets of Dhaka city strongly associated with the activities happening there. This is due to the design of the buildings along the traditional streets where five foot walkways act as a transition space between the street and the buildings. Here is where business transactions also take place apart from being a means of pedestrian access along the 
streets. Therefore, the streets become the place of economic activities. The streets therefore contribute as a major setting for human behavior in Dhaka city.

\subsection{RESEARCH METHODOLOGY}

The method for this study employed a case study approach to determine the users' perception of the physical attributes relevant to street hawking. A case study approach is used to generate an understanding of a complex issue in its real-life context (Yin, 2014). The sample size derived for this research stands at 400 based on the formula from Taro Yamane (1967) and the published sample table from Krejcie\& Morgan (1970). To obtain maximum variation of the respondents the researcher has used the convenience sampling strategy to make it quicker. Theunits of analysis for this study are the users and the urban public spaces. Nevertheless, the users' are classified into two groups; they are the street hawkers and the customers who visited in the particular area. Yet, the street traders were selected based on the types of commodity sold (i.e. food, goods, service), whereas the customer were selected based on their availability on the streets and frequency of buying goods from the street sellers. Multiple sources of evidences were used, for investigation including, questionnaire and survey through observation to analyze two contextual areas. $\mathrm{N}=400$ respondents were involved from two study areas of Dhaka city for the questionnaire survey. Thus the users involved with this activity were then divided equally for both sites (see Table 2). This application enabled the study to plan as well as to refine its routes to go in the right direction, and to apply appropriate research instruments at a particular time and place.

Table 1: Selection Criteria And Distribution of Respondents Among The Studied Areas

\begin{tabular}{|c|c|c|c|}
\hline \multirow{2}{*}{$\begin{array}{l}\text { Types of } \\
\text { User }\end{array}$} & Respondents selection criteria & \multicolumn{2}{|c|}{ No. of Respondents in each site } \\
\hline & Case 1 and Case 2 & Case 1 & Case 2 \\
\hline $\begin{array}{l}\text { Street } \\
\text { hawker }\end{array}$ & $\begin{array}{l}\text { - } \quad \text { Variation in commodity sold (i.e. food, goods, service) } \\
\text { - They have to by over } 20 \text { years of age } \\
\text { Respondents must be proficient in Bengali or English } \\
\text { language }\end{array}$ & 100 & 100 \\
\hline Customer & $\begin{array}{l}\text { - They have to by over } 20 \text { years of age } \\
\text { - Respondents must use the streets that are engaged with } \\
\text { street hawkers often } \\
\text { Respondents must be proficient in Bengali or English } \\
\text { language }\end{array}$ & 100 & 100 \\
\hline
\end{tabular}

Total $=400$

The questionnaire survey involved a series of structured questions to obtain information of four attributes of public places in relation to street hawking to get a complete overview of the current scenario. These attributes were deduced from literature and grouped into categories to gather substantial data on, sociability, uses and activities, access and linkage and physical safety, comfort and image acrossthe studied areas based on user's perception and desires. The data were analyzed through descriptive statistical measurements of percentage and central tendency. This study used likert scale for analyzing descriptive data. This type of data suggests to calculate the Median (average response) in search for the central tendency of each set of data (Brown, 2011; Maurer \& Pierce, 1998).

Before further analysis, the reliability of this survey was tested to determine the manner in which each sub-variables/sub- components effectively grouped together using SPSS. The reliability of the questionnaire instruments was tested using Cronbach's Alpha. In this study, the alpha ranged from 0.69 to 0.85 , which signifies that there is good for strong reliability within the 27 questions instrument (see Table 3).Survey through observation wasalso performed to validate the evidence through triangulation. 
Table 3: Reliability Statistics of Research instruments (questionnaire on attributes) in Case study 1 and Case study 2

\begin{tabular}{|c|c|c|c|c|c|c|}
\hline \multirow{3}{*}{$\begin{array}{l}\text { Attributes of } \\
\text { public spaces }\end{array}$} & \multirow{3}{*}{$\begin{array}{l}\text { Components of } \\
\text { attributes }\end{array}$} & \multirow{3}{*}{$\begin{array}{l}\text { No of } \\
\text { measuring } \\
\text { elements }\end{array}$} & \multicolumn{2}{|c|}{ Street Hawker } & \multicolumn{2}{|c|}{ Customer } \\
\hline & & & \multicolumn{2}{|c|}{ Cronbach's Alpha } & \multicolumn{2}{|c|}{ Cronbach's Alpha } \\
\hline & & & Case 01 & Case 02 & Case 01 & Case 02 \\
\hline \multirow[t]{2}{*}{ Sociability } & Demographic Pattern & \multirow{2}{*}{5} & \multirow{2}{*}{.722} & \multirow{2}{*}{.695} & \multirow{2}{*}{.784} & \multirow{2}{*}{.783} \\
\hline & Frequency of use & & & & & \\
\hline \multirow[t]{2}{*}{$\begin{array}{l}\text { Uses and } \\
\text { activities }\end{array}$} & $\begin{array}{l}\text { Physical condition of } \\
\text { the Street }\end{array}$ & \multirow[t]{2}{*}{8} & \multirow[t]{2}{*}{.803} & \multirow[t]{2}{*}{.850} & \multirow[t]{2}{*}{.821} & \multirow[t]{2}{*}{.801} \\
\hline & Distinctive Features & & & & & \\
\hline $\begin{array}{l}\text { Access and } \\
\text { linkage }\end{array}$ & $\begin{array}{l}\text { Mobility and } \\
\text { Accessibility in and } \\
\text { around the area }\end{array}$ & 4 & .686 & .796 & .789 & .774 \\
\hline \multirow{3}{*}{$\begin{array}{l}\text { Physical safety, } \\
\text { comfort and } \\
\text { image }\end{array}$} & Safety and security & \multirow{3}{*}{10} & \multirow{3}{*}{.798} & \multirow{3}{*}{.747} & \multirow{3}{*}{.710} & \multirow{3}{*}{.668} \\
\hline & $\begin{array}{l}\text { Environmental } \\
\text { condition of the Street }\end{array}$ & & & & & \\
\hline & Management & & & & & \\
\hline
\end{tabular}

\subsection{The Study Areas}

According to the statistics from Dhaka City Corporation (DCC), the city has approximately 5 million of street hawkers. Two popular and busy areas in Dhaka City which were selected as samples for this study, namely, Dhaka New Market and BaitulMukarram market, where numerous hawkers sell items for the daily needs of the people such as clothes, food and fruits, books, utensils, shoes andcosmetics.'DhakaNew Market' is one of the oldest shopping precincts of Dhaka city.Baitul Mukarram is popular and the largest mosque in Bangladesh, it is located in the commercial area. The roads are always busy with street hawking, continuous movement of the rickshaw, bus, bike, however moving of restless men and women. Along with multistory market all roads sides of Baitul Mukarram have temporary hawkers' shops.

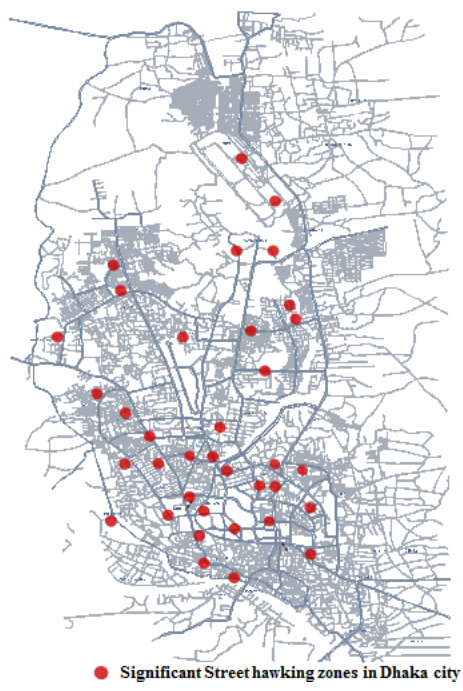

(a)

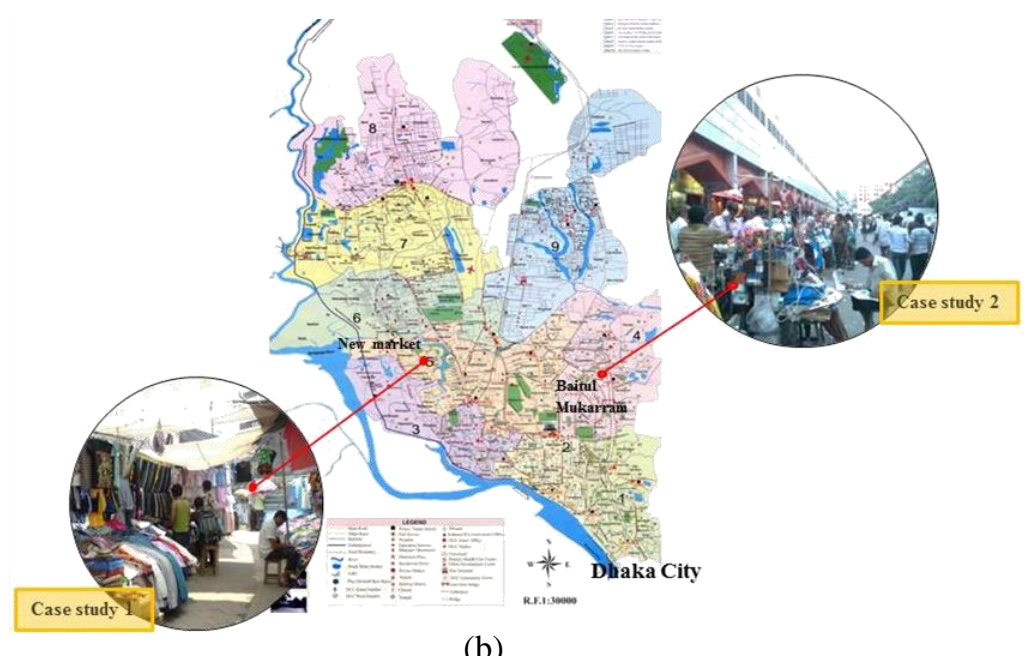

(b)

Figure1: (a) Street hawkers conquer the city spaces in Dhaka city;(b) Case study areas 


\subsection{RESULT AND FINDINGS}

Many scholars evaluate the qualities of successful public places (Appleyard, 1981; Gehl, 1987;Peter Buchanan, 1988; Whyte, 1988; Carmona et al., 2010).Grounded on literature, the investigations were described through comparative analysis of case study 1 and 2 according to the identified attributes in search for the impact of street hawking in the existing urban spaces of Dhaka city. The findings explained on the following parameters:

\subsection{Sociability Elements Across The Case Study Areas}

A place must comprehend sociability character of its own (Gehl, 1987). Here from the areas; the demographic pattern, hawking locations, frequency of visit the areas and the dimensions of activity in relation to urban spaces were examined as the components of sociability character of the studied areas.

Table 4:Elements of Sociability identified for this study

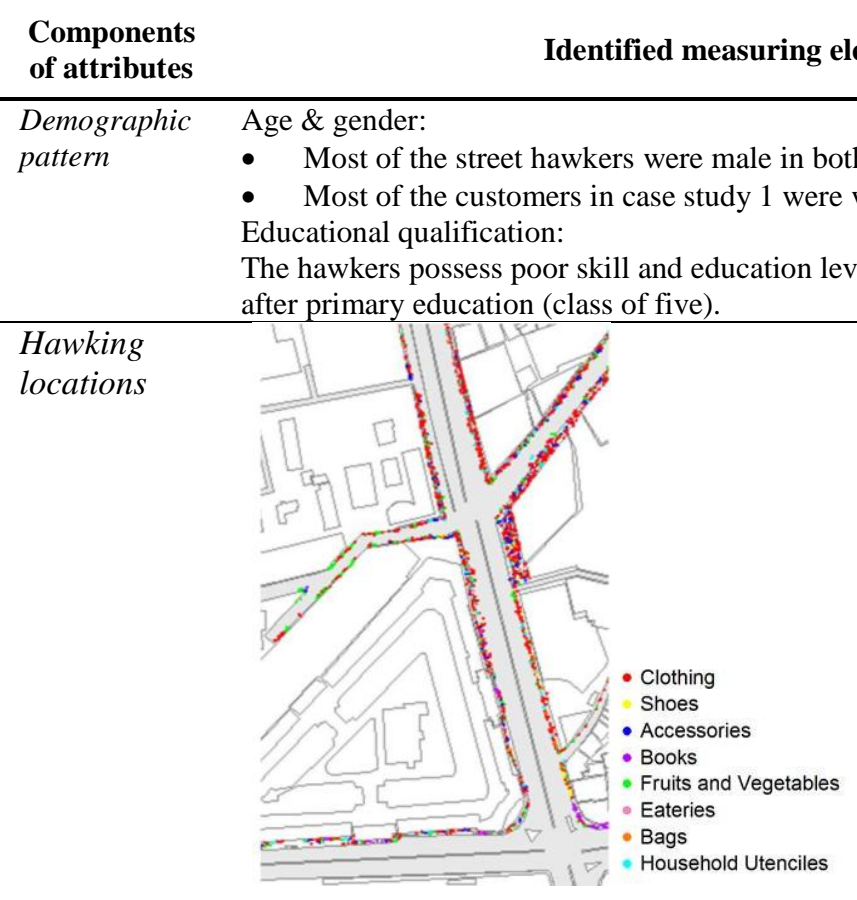

Case study 1

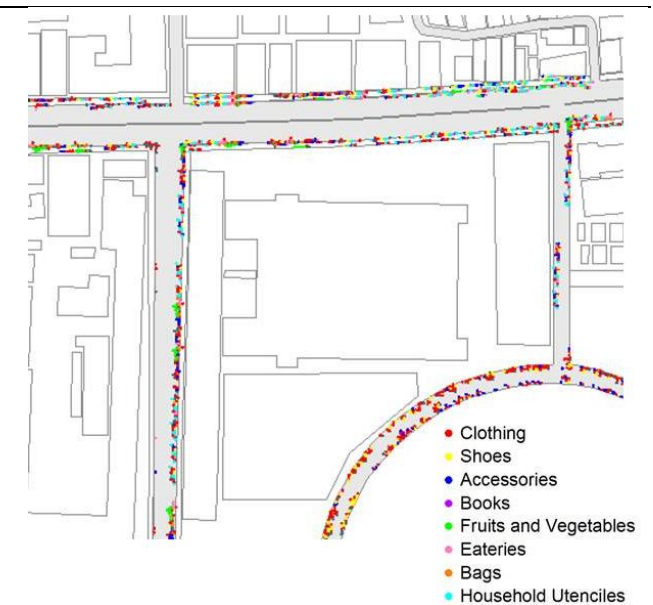

Case study 2

Hawkers locate themselves near entry points and in front of streets that face retail centers and public places.

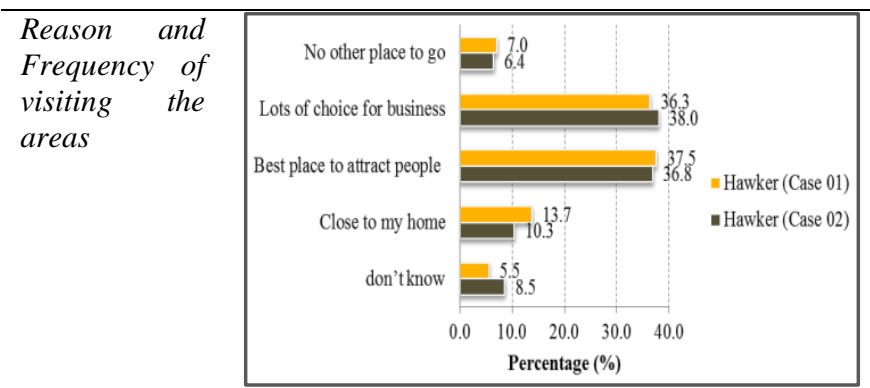

Reason for choice of specific location of the street hawkers in Case study 1 and 2

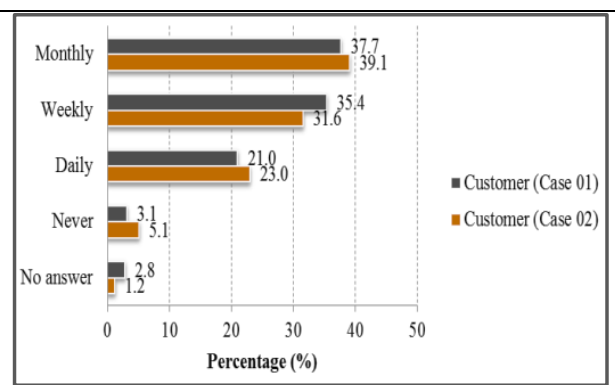

Frequency of buying goods from street hawkers in Case study 1 and 2

Dimensions of Migration, lack of education, lower skills and insufficiency of job, demand, and scarcity of land, activity lower investment, and encroachment of footpath and so on, describes the social, economic and environmental dimensions, which drives the people to be on the street as street hawker. 
There are approximately 4,000 street hawkers in and around Case study 1 and 2.Marginalized community, general middle to low income people are the main customers of these street markets. There is no proper alignment and location of street stalls along Case study 1 and Case study 2 (see Table 4). As can be observe in the table, the stalls over the footpath, occupied more than half of its width. It had been quantified that street hawkers of Case 1 and 2 have to attend approximately above 150 consumers every day. It reveals their importance to the city community on daily basis. The physical location of the hawkers through observation survey demonstrated the uncontrolled existence of the hawkers in both cases. Despite of all these issues a large number of city dwellers depend on this activity to serve their daily needs. 'A sociable place should encompass people friendly environment in which act as Meeting place, as Market place or as Connection place'- this has supported by Gehl to clarify how to make a useful public spaces (Gehl, 1987). In this study, the relevant elements of 'Sociability'character of an area, explainingthe importance of creating amiability in the urban spaces.

\subsection{Elementsof Uses And Activities Across The Study Areas}

The surveys reflect the significance of the users' perception on uses and activities in and around the studied areas through the nature and pattern of the activity, space configuration of the street stalls and physical and distinctive features of the areas.

The pattern of operation of the street hawkers in the study areas is classified into four types, they are: Permanent, Semi - permanent, Semimobile, and Mobile. In Case 1 the permanent street sellers are near to half (41.2\%) among all the types. The second highest is the semi mobile type (27.9\%). Furthermore, in Case 2, the leading hawker groups are the semi-permanent type $(35.8 \%)$.The field survey found that basically there are three types of space configuration of stalls, which are, direct access, single access and through and across the access. Through spot observation, these types of space configuration depend on the location and varieties of selling goods.

In addition, the physicaland distinctive features reflected the settings of theareas to become useful for the users' daily activities. Results from the survey shown in Table 5 indicate the degree of perception of the users' of Case study 1 and 2 is between the scale of 2 and 1, which are below average suggesting the users' dissatisfaction with the current condition. The evaluation through observation in the studied areas reveals the similar results as users' perception which validates the descriptive survey

Table 5: Physical and distinctive elements identified by the users' in Case study 1 and 2

\begin{tabular}{|c|c|c|c|}
\hline \multirow{3}{*}{$\begin{array}{l}\text { Components of } \\
\text { attributes }\end{array}$} & \multirow{3}{*}{ Identified measuring elements } & \multicolumn{2}{|c|}{ Users' Perception } \\
\hline & & Case 1 & Case 2 \\
\hline & & \multicolumn{2}{|c|}{ Median value } \\
\hline \multirow{5}{*}{$\begin{array}{l}\text { Physical condition of } \\
\text { the street }\end{array}$} & The width of the footpath is sufficient for the users' & 2 & 2 \\
\hline & Every hawker has proper hawking area demarcation & 1 & 1 \\
\hline & Street shelters and canopies are adequate for the users & 2 & 2 \\
\hline & Paving and flooring are suitable for the users & 1 & 1 \\
\hline & The street furniture \& seating will make the place more busy & 2 & 1 \\
\hline \multirow{3}{*}{$\begin{array}{l}\text { Distinctive features of } \\
\text { the area }\end{array}$} & There are so many choices of stuffs & 2 & 1 \\
\hline & This place is people-friendly & 1 & 1 \\
\hline & This area is distinctive for running business/ buying & 1 & 1 \\
\hline
\end{tabular}

*Note: $N=400$. (Equally distributed in each area),

Response format: $1=$ strongly disagree, $2=$ Disagree, $3=$ Neutral, $4=$ Agree, $5=$ strongly agree 

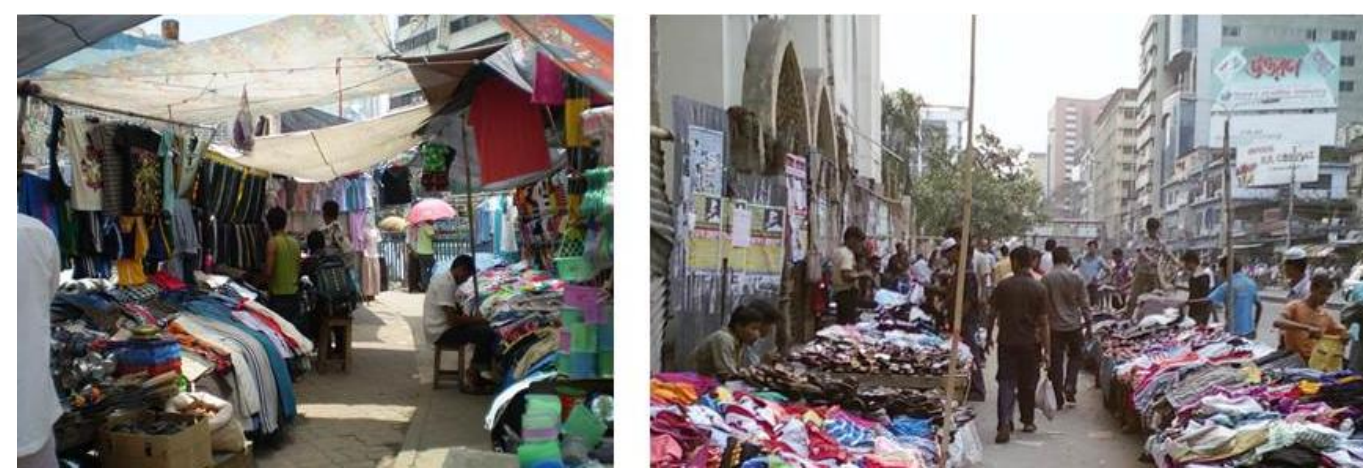

Figure 2: A view of physical and distinctive features around Case study 1 (left) and Case study 2 (right)

Street activities in Dhaka are basically featured on street hawking. There is not enough reason to come to the particular places only, except aiding daily needs. The questionnaires and observations validate the reasons why the supporting elements of uses and activities of public spaces could not satisfy the users of the Case study 1 and 2 . This is reflected by the insufficiency width of the footpath, inadequate street shelters and canopies and inappropriate paving and flooring, as can be seen in figure 2 , are deteriorating the quality of the spaces. The findings of this research supports the results of previous studies, especially the 'Livable Streets'; which revealed the effects of movement on deterioration of streets' livability
(Appleyard, 1981), findings on Switzerland's streetscapes (Sauter, 2008) or the study about the physical features on the walkability of an area by (Forsyth, 2008).

\subsection{Mobility And AccessibilityElementsAcross the areas}

A successful public space must have the quality of easy to get to and get through and are convenient to public transit. Thesurvey results on the user's perception ofthe elements of mobility and accessibility in Case study 1 and 2 in Table 6indicated that scale of agreement with the

current condition is below average whichsuggestedthe negative impression and dissatisfaction with the place relevant elements

Table 6:Mobility and Accessibility elements identified by the users' in Case study 1 and 2

\begin{tabular}{|c|c|c|c|}
\hline \multirow{3}{*}{ Components of attributes } & \multirow{3}{*}{ Identified measuring elements } & \multicolumn{2}{|c|}{ Users' Perception } \\
\hline & & Case 1 & Case 2 \\
\hline & & \multicolumn{2}{|c|}{ Median value } \\
\hline \multirow[t]{4}{*}{$\begin{array}{l}\text { Mobility and Accessibility } \\
\text { in and around the area }\end{array}$} & $\begin{array}{l}\text { The hawkers' stall placed properly on the street, which never } \\
\text { disrupts the walkability of the public. }\end{array}$ & 2 & 2 \\
\hline & The hawking activity has created a clear overview of the street & 2 & 1 \\
\hline & $\begin{array}{l}\text { The placement of hawking stuff, not ever create traffic } \\
\text { congestion. }\end{array}$ & 1 & 1 \\
\hline & Adequate Parking space satisfies the users & 1 & 1 \\
\hline
\end{tabular}

*Note: $N=400$. (Equally distributed in each area)

Response format: $1=$ strongly disagree, $2=$ Disagree, $3=$ Neutral, $4=$ Agree, $5=$ strongly agree 

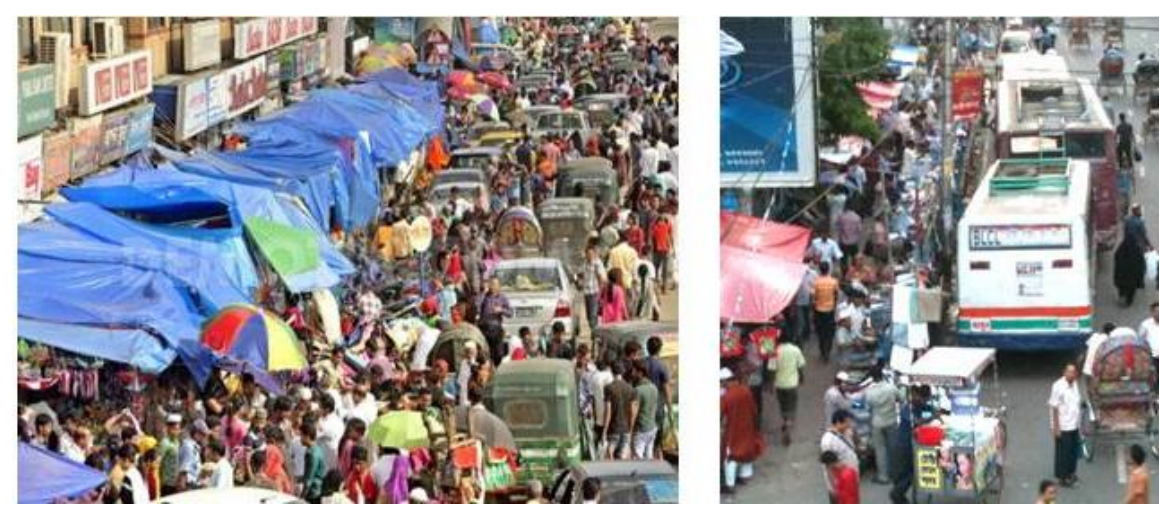

Figure3:A view of Mobility and Accessibilityfeatures around Case study 1 (left) and Case study 2 (right)

The findings discovered that the studied areas are in a vulnerable condition according to the identified issues. As vehicular space increases, pedestrian allocated space decreases, resulting in pedestrian marginalization from city spaces and increased traffic congestion, accident and other fatalities. However, the above identified issues have proven that the impact of street hawking deteriorating the quality of accessibility and linkage of the studied areas. In the same way, The Project for Public Spaces claimed that, "The accessibility of a place is judged by its connections to its surroundings, both visual and physical. A successful public space is easy to get to and get through; it is visible both from a distance and up close. The edges of a space are important as well: For instance, a row of shops along a street is more interesting and generally safer to walk by than a blank wall or empty lot. Accessible spaces have a high parking turnover and, ideally, are convenient to public transit" (P.P.S, 2001).

\subsection{TheElementsOfPhysical Safety, Comfort And Image Across The Study Areas \\ The majority of the users' perceived that safety and security are the foremost concern in supporting this activity. The results revealed that the users'from both study areashave a negative thought on the elements related to safety, comfort and image in the studyareas. The scale value of the agreement is between 2 and 1 , which is below average (see Table 7). Users from both case study areas confirm the statements as problems in the particular areas.}

Table 7:Elementsof Safety, Comfort and Image identified by the users' in Case study 1 and 2

\begin{tabular}{llcc}
\hline \multirow{2}{*}{$\begin{array}{c}\text { Components of } \\
\text { attributes }\end{array}$} & \multicolumn{1}{c}{ Identified measuring elements } & Users' Perception \\
\cline { 3 - 4 } & & Case 1 & Case 2 \\
\cline { 2 - 4 } Safety and security & The footpath is secured for the users & 2 & Median value \\
& Here is no threaten of crime, disorder and victimization & 1 & 2 \\
\hline Environmental & Users are comfortable with the Hygiene of the area & 1 & 1 \\
condition & The noise level of the area is tolerable for the users' & 2 & 1 \\
& The lighting system for night is sufficient for the users' & 1 & 2 \\
& Users are satisfied with the cleanliness of the street & 2 & 2 \\
\hline
\end{tabular}

*Note: $N=400$. (Equally distributed in each area)

Response format: $1=$ strongly disagree, $2=$ Disagree, $3=$ Neutral, $4=$ Agree, $5=$ strongly agree

The findings on the physical safety, comfort and image of public spaces revealed the sufferings ofthe users' of case study 1 and 2. They are often victimized by the disorder and poor management system and lack of safety and security. The findings sustained the relationship of safety, maintenance and landscape issues with the street hawking, which also reinforces the previous research of (Gehl, 1987); (Bentley, Alcock, McGlynn, Murrain, \& Smith, 2008) and (Marcus \& Francis, 1998). 


\subsection{DISCUSSION}

The study set out to explore how the physical attributes of public spaces influence the hawking activity. Although understanding the users' perception is important, the focus is placed on getting an insight into the actual scenario. The survey indicated that there are lack of precision of the attributes of public spaces due to the unsuitable uses and activities of the spaces, inappropriate accessibility and linkage between the inner and outer spaces and inadequate safety and comfort in and around the hawking areas for both case study areas. The findings confirm earlier studies which revealed common results to verify this study. However, it is regretful that the current streets of both studied areas are still suffering from physical problems which deteriorate their quality, since the notion of significance of physical attributes of public spaces were defined five decades ago. There are similarities between users' perception and observation survey as can be seen from the replication in case study 1 and case study 2 as shown in Table 8.

Table 8: Overall Comparative analysis between two studied areas

\begin{tabular}{l|l}
\hline \multicolumn{1}{c}{ Case study 01 } & \multicolumn{1}{c}{ Case study 02 } \\
\hline Sociability & \\
\hline The observation technique (street layout and hawking locations), and questionnaire survey (demography and \\
frequency of using the areas) findings revealed that in both cases the street hawkers operate their business \\
wherever they can get accommodation. Thus, they face harassment by the local authorities on a daily basis. \\
The physical location of the hawkers through observation survey demonstrated the uncontrolled existence of \\
the hawkers in both cases.
\end{tabular}

\begin{tabular}{|c|c|}
\hline \multicolumn{2}{|l|}{ Access and linkage } \\
\hline $\begin{array}{l}\text { - Users' raised many issues about poor } \\
\text { connectivity and accessibility especially related } \\
\text { to informal street hawking in the public spaces. } \\
\text { - There is a general agreement among people on } \\
\text { the need for good street view with variety of } \\
\text { other uses, like, street activities with organized } \\
\text { hawking, events, relaxing, etc. } \\
\text { - Car traffic environment with illegal traffic } \\
\text { activities poses as an unsafe environment which } \\
\text { causes insecurity among the pedestrians. }\end{array}$ & $\begin{array}{l}\text { - The unorganized placement of hawking stalls } \\
\text { disrupts the walkability of public. People agreed } \\
\text { that when walking between destinations, there is } \\
\text { no easy access, which forces pedestrians to walk } \\
\text { on road. There is also obstruction due to poor } \\
\text { site maintenance. } \\
\text { It was a common agreement that there is in need } \\
\text { to give adequate parking space according to city } \\
\text { planning rules and take actions against illegal } \\
\text { parking. }\end{array}$ \\
\hline \multicolumn{2}{|l|}{ Physical safety, comfort and image } \\
\hline $\begin{array}{l}\text { People agreed that there needs to be } \\
\text { improvement of elements of security and safety } \\
\text { in the surrounding areas of the sites. } \\
\text { - Users' complained of dim street lights which } \\
\text { makes them feel insecure while walking or } \\
\text { doing business. }\end{array}$ & $\begin{array}{l}\text { - Safety and security facilities are the primary } \\
\text { facilities that need to be looked into. } \\
\text { Poor lighting system for night, } \\
\text { insufficientgranarydiscourage the public to walk } \\
\text { on the footpath. }\end{array}$ \\
\hline
\end{tabular}

84 Journal of Design and Built Environment Vol. 17 (1), June 2017 Abontika S. \& Mastura A. 
- Users' didn't see any attractive greenery around the site.

\subsection{CONCLUSION}

This research explores the challenges that people encounter in understanding the importance of street hawking. This study is an approach to the on-going research surrounding sustainable urban public spaces in Dhaka with a focus on the physical facilities of informal street hawking for the quality improvement. This study attempts to Link Street hawking with a range of life quality issues. Street hawking remains as a temporary business activitygiven the lack of authority involvement and sustainable management. In order to enhance the livability of Dhaka City, healthy urban designs, planning, and facilities must be developed through improved governance and management. The development of the 'street 7.0 REFERENCES

Al'.Aswad,\&Achmad.Djunaedi.(2015). $\quad$ THE INFORMAL SECTOR OF SHAPING CITY COMMERCIAL OPEN SPACE.International Journal of Advanced Research, 3(6), 451-454

Appleyard, D. (1981). Livable streets. Berkeley: University of California Press.

Bentley, I., Alcock, A., McGlynn, S., Murrain, P., \& Smith, G. (2008).Responsive environments : A manual for designers. Oxford: Butterworth Architecture

Bhowmik, S. K. (2005). Street Vendors in Asia: A Review. Economic and Political weekly, 40(22/23), 2256-2264.

Brown, A. (2006). Contested Space: Street Trading, Public Space and Livlihoods in Developing Cities. Rugby: ITDG Publishing.

Brown, J. D. (2011). Likert items and scales of measurement. Shiken: JALT Testing \& Evaluation SIG Newsletter, 1, 10-14.

Buchanan, P. (1988). Facing up to facades. Architects journal, 188, 21-56.

Carmona, M., Tiesdell, S., Heath, T., \& Oc, T. (2010). Public Places- Urban Spaces: The Dimensions of Urban Design (2nd ed.). London: Routledge.

Dewar, D., \& Watson, V. (1990). Urban markets, developing informal retailing. London and New York: Routledge.

Duany, A., Plater-Zyberk, E., \& Speck, J. (2000). Suburban nation: The rise of sprawl and the hawking' proposed in this study to the relevant practitioners and stakeholders is seen in several ways like, some internal road can be vehicle free pedestrian road, improvement of the physical and environmental features, users' needs should be fulfilled for enhancing their experience while running a business or buying goods or even walking in Dhaka city.Yet, the physical attributes strongly influence the physical quality of the environment as well as the psychological wellbeing of the users', it is believed that, people will be more encouraged to walk on the footpath through proper space organization forthis activity in the city center and enjoy themselves while doing so.

decline of the American dream. New York: North Point Press.

Findly, A. M., Paddison, R., \& Dawson, J. A. (1990). Retailing Environments in Developing countries. London: Routledge.

Forsyth, A., Hearst, M., Oakes, J. M., \& Schmitz, K. H. (2008). Design and destinations: Factors influencing walking and total physical activity. Urban Studies, 45(9), 1973-1996.

Francis, M. (1991). The making of democratic streets. In A. V. Moudon (Ed.), Public streets for public use. New York: Columbia University Press.

Frey, H. (1999). Designing the city: Towards a more sustainable urban form. E \& FN Spon, London.

Gehl, J. (1987). Life between Buildings: Using Public Space. New York: Van Nostrand Reinhold.

Hossain, N. (2001). The Spatial Structure of 'Spontaneous' Retail Development in Dhaka City. Unpublished Doctoral Thesis. The Bartlett School of Graduate Studies, University College London, University of London.UK.

Krejcie, R. V., \& Morgan, D. W. (1970). Determining sample size for research activities. . Educational and Psychological Measurement, 30, 607-610.

Krier, R. (1979). Urban Space. London: Academy Editions.

Lynch, K. (1960). The image of the city. Mass: MIT Press. 
Lynch, K. (1981). A Theory of Good City Form (1st ed.): MIT Press.

Marcus, C., \& Francis, C. (1998). People Places: Design Guidlines for Urban Open Space (2nd ed.). New York: Jhon Wiley \& Sons, Inc.

Maurer, T. J., \& Pierce, H. R. (1998). A comparison of Likert scale and traditional measures of self-efficacy. Journal of applied psychology, 83(2), 324.

Montgomery, J. (1998). Making a city: urbanity, vitality and urban design. Journal of Urban Design, 3(1), 93-116.

Nilufar, F. (1999). Urban life and use of Public Space Study of responsive public open spaces for supporting urban life in Dhaka City. The Asiatic Society of Bangladesh. Dhaka.

Parvin, K. (2007). Hawkers find holiday market inadequate to liveby, New Age.

P.P.S. (2001). How to turn a place around:A hand book for creating successful public spaces. New York: Project for Public Spaces, Inc.

Proshansky, H. M., Fabian, A. K., \& Kaminoff, R. (1995). Place Identity: Physical world socialisaion of the self, giving places meaning. Readings in Environmental Psychology, 87-113.

Relph, E. (1976). Place and Placelessness. Pion, London.

Rubenstein, H. M. (1992). Pedestrian malls, streetscapes, and urban spaces. New York, NY: John Wiley \& Sons Inc.
Sauter, D., \& Huettenmoser, M. (2008). Liveable streets and social inclusion. Urban Design International, 13(2), 67-79.

Shaftoe, H. (2008). Convivial urban spaces: Creating effective public places. Retrieved from <http://site.ebrary.com/lib/malaya/docPrint.a ction?>.

Shuhana, S., Norhaslina, J., \& Maslyana, M. (2004). Criteria of success for traditional shopping streets in Malaysia: Case study of Kuala Lumpur. Universiti Teknologi, Malaysia.

Shuhana, S., \& Norsidah, U. (2008). Making places: The role of attachment in creating the sense of place for traditional streets in Malaysia. Habitat International 32 399-409.

Wagner, F., \& Caves, R. (2012). Community livability: Issues and approaches to sustaining the well-being of people and communities. London: Routledge.

Whyte, W. (1988). City: Rediscovering the Center Philadelphia: University of Pennsylvania press.

Yankson, P. W. K. (2000). Accommodating Informal Economic Units in the Urban Built Environment: Petty Commodity Enterprises in the Accra Metropolitan Area, Ghana. Third world planning review, 313-334.

Yamane, Taro. (1967). Statistics: An Introductory Analysis, 2nd Edition, New York: Harper and Row.

Yin, R. K. (2014). Case Study Research: Design and Methods (th Ed.). London: SAGE Publications 